\title{
Penerapan SAK EMKM Sektor Pertanian Kabupaten Bogor Menuju Pengembangan Industri 4.0
}

\author{
Enok Rusmanah ${ }^{1}$ \\ Fakultas Ekonomi dan Bisnis \\ Universitas Pakuan, Indonesia
}

\author{
Nizam Mohammad Andrianto ${ }^{2}$ \\ Fakultas Ekonomi dan Bisnis \\ Universitas Pakuan, Indonesia
}

\begin{abstract}
Surel : enok.rusmanah@unpak.ac.id
\section{ABSTRAK}

Usaha Mikro, Kecil, dan Menengah (UMKM) merupakan penggerak utama perekonomian dan didominasi sektor pertanian. Namun UMKM sektor ini tidak menunjukkan peningkatan yang signifikan. Salah satu kendalanya adalah kesulitan akses UMKM terhadap pembiayaan akibat laporan keuangan yang kurang dapat dipercaya. SAK EMKM disusun untuk menjawab tantangan ini. Oleh karena itu penelitian ini termotivasi untuk mengetahui bagaimana persepsi para pelaku UMKM sektor pertanian, terhadap SAK EMKM. Penelitian ini dilakukan di Kabupaten Bogor dengan responden para petani di sektor pertanian. Analisis deskriptif berdasarkan konsep Technology Acceptance Model dari Davis (1989) digunakan untuk memetakan bagaimana persepsi pelaku UMKM ini. Hasilnya menunjukkan bahwa responden umumnya setuju SAK EMKM bermanfaat tetapi tidak setuju jika SAK EMKM ini mudah untuk diterapkan.
\end{abstract}

\section{Kata Kunci: UMKM; SAK EMKM; Technology Acceptance Model.}

\section{Implementation of SAK EMKM in the Agricultural Sector of Bogor Regency towards Industrial Development 4.0}

\section{ABSTRACT}

Micro, Small, and Medium Enterprises (MSMEs) are the main drivers of the economy and dominated by the agricultural sector. However, this sector does not show a significant improvement. The main obstacle is the lack of MSME access to financing due to reliable financial reports. Financial Accounting Standards for MSMEs (SAK EMKM) were prepared to address this challenge. This study motivates to determine the perceptions of MSME of agricultural sector towards SAK EMKM. The study is done in Bogor Regency with farmers as the respondens. Descriptive analysis and Technology Acceptance Model (TAM) by Davis (1989) are combined to explain the perceptions. The results show that SAK EMKM was usefull but did not agree that it was easy to implement.

Keywords: $\quad$ UMKM; SAK EMKM; Technology Acceptance Model.

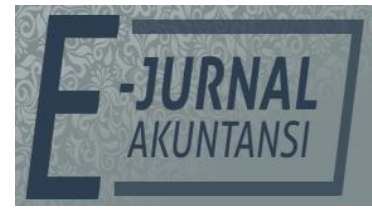

e-ISSN 2302-8556

Vol. 31 No. 5

Denpasar, Mei 2021

Hal. 1216-1228

DOI:

10.24843/EJA.2021.v31.i05.p11

PENGUTIPAN

Rusmanah, E., \& Andrianto, N.M. (2021). Penerapan SAK

EMKM Sektor Pertanian

Kabupaten Bogor Menuju Pengembangan Industri 4.0.

E-Jurnal Akuntansi, 31(5),

$1216-1228$

RIWAYAT ARTIKEL:

Artikel Masuk:

21 Desember 2020

Artikel Diterima: 24 Mei 2021

Artikel dapat diakses : https://ojs.unud.ac.id/index.php/Akuntansi/index 


\section{PENDAHULUAN}

Indonesia termasuk salah satu negara yang mengandalkan sektor usaha mikro, kecil dan menengah untuk membantu meningkatkan pembangunan ekonominya. Hal ini terbukti pada usaha pemerintah yang intensif dalam membantu mengembangkan sektor ini. Bahkan Usaha Mikro, Kecil, dan Menengah (UMKM) diklaim sebagai penggerak utama perekonomian negara. Pada pertengahan tahun 2018, Presiden Joko Widodo menyatakan UMKM di Indonesia menyumbang sekitar 60 persen pertumbuhan ekonomi nasional dengan 49 persen dari UMKM didominasi oleh sektor pertanian (Putra, 2018).

Namun demikian fakta menunjukkan persentase ini tidak mengindikasikan perubahan signifikan dari tahun-tahun sebelumnya. Salah satu kendala utama tidak berkembangnya sektor ini adalah kurangnya akses UMKM terhadap pembiayaan dan informasi kredit. Bahkan kredit perbankan yang disalurkan hingga bulan Mei 2018 hanya sebesar 20,69 persen (Yasmin, 2018). Selain masalah pembiayaan dan informasi kredit, kendala lain yang dihadapi UMKM saat ini adalah masih banyaknya pelaku usaha yang tidak melek teknologi, terbukti hanya sekitar 5 persen usaha yang telah go-digital (Purbaya, 2019).

Faktanya juga kondisi ini tidak hanya terjadi di Indonesia, hampir semua negara menghadapi masalah yang sama terkait dengan pembiayaan UMKM, yaitu sulitnya mendapat pembiayaan dan sulitnya akses terhadap kredit modal. Abdelhafid \& Mohammed (2019) menyatakan masalah pembiayaan dan kredit ini umum terjadi sebagai akibat adanya asimetri informasi antara lembaga keuangan dengan pelaku usaha. Kurangnya informasi penglolaan keuangan membuat lembaga keuangan enggan memberikan kredit karena menganggap struktur keuangan UMKM lemah. Oleh karena itu IAI (Ikatan Akuntan Indonesia) menyusun sebuah Standar Akuntansi Keuangan untuk Entitas Mikro, Kecil, dan Menengah (SAK EMKM) sebagai acuan yang dapat digunakan oleh UMKM dalam menyusun laporan keuangan. SAK EMKM ini diharapkan dapat meningkatkan transparansi dan akuntabilitas pelaporan keuangan EMKM yang pada akhirnya meningkatkan pertumbuhan sektor ini.

Selain pembiayaan dan akses modal, saat ini UMKM menghadapi tantangan yang lebih besar yaitu masuknya dunia bisnis ke era indsutri 4.0. Mau tidak mau, para pelaku usaha harus menyesuaikan dengan tuntutan global, begitu juga dengan UMKM. Pada era industri 4.0 ini, dunia digital memiliki peran penting. Hal ini dikarenakan digitalisasi telah menyentuh hampir semua segi kehidupan termasuk sektor industri dan proses bisnis dari produksi hingga promosi untuk menciptakan jejaring dan peluang pasar (Schröder, 2016).

Penelitian ini memiliki motivasi untuk mengetahui persepsi pelaku UMKM terutama untuk sektor pertanian terhadap kegunaan dan kemudahan SAK EMKM. Selanjutnya ingin diketahui pula persepsi para pelaku UMKM sektor pertanian ini terhadap pengelolaan keuangan, efektifitas penerapan SAK EMKM, dan strategi pengembangan bisnis berbasis digital dan online. Kontribusi penelitian ini adalah menambah wawasan bagaimana persepsi para pelaku UMKM khususnya di sektor pertanian terhadap kegunaan dan kemudahan penerapan SAK EMKM, mengingat sektor ini masih menjadi penopang dan ciri khas ekonomi masyarakat Indonesia. 
Usaha Mikro, Kecil, dan Menengah (UMKM) merupakan kegiatan usaha yang dicanangkan pemerintah dapat meningkatkan perekonomian nasional. Menurut Undang-Undang Nomor 20 Tahun 2008 tentang Usaha Mikro, Kecil, dan Menengah, usaha mikro, kecil, dan menengah adalah usaha ekonomi produktif milik orang perorangan dan/atau badan usaha yang bukan merupakan anak perusahaan, atau cabang perusahaan yang dimiliki, dikuasai baik secara langsung maupun tidak langsung sesuai dengan kriteria usaha mikro, kecil, dan menengah (Anonim, 2008).

Sebagai sektor yang diandalkan untuk memperluas lapangan pekerjaan, memberikan pelayanan kepada masyarakat luas, memeratakan pendapatan, meningkatkan pertumbuhan ekonomi, dan stabilitas nasional, peran UMKM sangat berat mengingat masih banyak kendala yang dihadapi sektor ini termasuk UMKM yang bergerak di bidang pertanian. Menurut laporan, sektor UMKM merupakan penyumbang terbesar PDB dengan 49 persen didominasi oleh sektor pertanian (Putra, 2018). Namun kenyataannya sektor pertanian tidak mengalami pertumbuhan bahkan beberapa wilayah mengalami penurunan salah satunya di Kabupaten Bogor. Masyarakat yang berprofesi sebagai petani semakin menurun dari tahun ke tahun (Maulana, 2019).

Kendala yang paling umum dihadapi oleh UMKM adalah masalah pembiayaan dan sulitnya akses terhadap kredit modal dari lembaga keuangan atau pemberi donor. Fenomena ini tidak hanya terjadi di Indonesia, hampir semua negara yang mengandalkan sektor UMKM dalam perekonomian negaranya mengalami hal serupa (Kersten, Harms, Liket, \& Maas, 2017). Kendala ini terjadi diduga adanya asimetri informasi antara pelaku UMKM dengan lembaga keuangan (Abdelhafid \& Mohammed, 2019). Di Aljazair misalnya, Abdelhafid \& Mohammed, (2019) menyatakan, kurangnya informasi mengenai produksi UMKM dan struktur keuangan yang lemah membuat bank enggan memberikan kredit. Begitu juga di China, asimetri informasi menyebabkan sering dihentikannya kredit modal untuk UMKM (Huang, When, \& Liu, 2014). Bahkan kredit untuk petani seringnya didapat dari pasar kredit informal daripada lembaga formal karena mahalnya biaya kredit formal (Tang \& Guo, 2017). Dan bisa jadi bank tidak dapat membedakan peminjam yang berisiko lemah dengan yang berisiko tinggi (Saito \& Tsuruta, 2018).

Tantangan selanjutnya yang dihadapi oleh UMKM sektor pertanian yaitu dimasukinya revolusi industri 4.0. Pada era ini penggunaan digital memegang peran penting, bahkan digitalisasi menyentuh hampir semua sektor kehidupan manusia. Dunia bisnis dituntut untuk menyesuaikan proses bisnis dari mulai produksi produk sampai promosi dengan menciptakan jejaring dan peluang pasar melalui digital marketing (Rusmanah, Andria, \& Irawan, 2019). Dengan demikian dapat disimpulkan era industri 4.0 ini mau tidak mau mempengaruhi juga bagaimana pelaku UMKM mengembangkan bisnisnya (Önday, 2018).

Beberapa penelitian telah dilakukan untuk mengidentifikasi faktor apa saja yang mempengaruhi penerapan standar akuntansi pada UMKM. Hasil penelitian Deaconu dan Buiga menyatakan bahwa negara-negara berkembang cenderung mengadopsi secara langsung IFRS (International Financial Reporting Standards), standar yang berlaku internasional, untuk UMKM dengan alasan meniru negara maju tanpa mempertimbangkan kesulitan penerapan oleh pelaku UMKM 
(Deaconu \& Buiga, 2015). Kaya dan Koch mengemukakan bahwa alasan standar akuntansi internasional untuk UMKM diadopsi adalah mengatasi kos pembiayaan pelaporan keuangan (Kaya \& Koch, 2015). Namun, hal yang mempengaruhi diterapkannya standar akuntansi oleh para pelaku UMKM, ternyata adalah persepsinya terhadap kegunaan dari standar itu sendiri .

Di Indonesia, standar akuntansi keuangan untuk UMKM tidak mengadopsi IFRS for SMES. Untuk membantu memenuhi kebutuhan pelaporan keuangan UMKM, IAI (Ikatan Akuntan Indonesia) menyusun sebuah standar yaitu Standar Akuntansi Keuangan Entitas Mikro, Kecil, dan Menengah (SAK EMKM) sebagai acuan bagi pelaku UMKM terutama bagi yang memiliki keterbatasan sumber daya manusia. Standar ini berlaku efektif 1 Januari 2018. Standar yang dikembangkan secara domestik ini diharapkan dapat memperkecil gap asimetri informasi antara pelaku UMKM dan lembaga keuangan, sehingga sektor ini mengalami pertumbuhan.

Penelitian Agung et al. menemukan bahwa pendidikan, pemahaman teknologi informasi, sosialisasi, dan pelatihan tidak mempengaruhi terhadap penerapan standar akuntansi (Agung, Latuheru, \& Persuless, 2018). Penerapan standar akuntansi ternyata dipengaruhi oleh persepsi kegunaan dan kemudahan dari pelaku UMKM, terbukti pada implementasi standar akuntansi oleh UMKM Kota Bandung (Nerissa \& Hapsari, 2018). Hal ini sejalan dengan penelitian yang dilakukan oleh (Perera \& Chand, 2015).

Technology Acceptance Model (TAM) dari (Davis, 1989) merupakan sebuah model analisis yang menjelaskan perilaku user/pengguna terhadap suatu teknologi informasi baru (Rizal, 2014). Model ini awalnya diangkat untuk mengidentifikasi perilaku penerimaan dari karyawan terhadap sebuah penerapan teknologi informasi dalam industri. Namun seiring dengan waktu model ini banyak diterapkan juga untuk kasus-kasus lain seperti implementasi ERP (Amoako-Gyampah \& Salam, 2004), (Erasmus, Rothmann, \& Van Eeden, 2015), dan (Yasar \& Gokhan, 2012). Bahkan model ini banyak dikembangkan peneliti setelahnya dengan memodifikasi faktor-faktor yang mempengaruhi persepsi kegunaan dan kemudahan seperti implementasi standar akuntansi (Kiliç, Uyar, \& Ataman, 2016), dan (Permatasari, Yanto, \& Widiyanto, 2017).

Akuntansi diartikan sebagai seperangkat pengetahuan yang mempelajari perekayasaan penyediaan jasa berupa informasi keuangan kuantitatif unit-unit organisasi dalam suatu lingkungan negara tertentu dan cara penyampaian (pelaporan) informasi tersebut kepada pihak yang berkepentingan untuk dijadikan dasar dalam pengambilan keputusan ekonomik (Suwardjono., 2016). Dari definisi ini, akuntansi dapat dipandang sebagai suatu teknologi sehingga TAM sesuai untuk analisis penelitian ini.

Adanya kendala informasi keuangan sehingga menyulitkan pembiayaan dan akses kredit yang dihadapi UMKM membuat IAI menyusun sebuah panduan berupa SAK EMKM tahun 2018. Tetapi bagaimana SAK ini diterapkan pengelola UMKM dalam pengelolaan keuangannya? Technology acceptance model dapat digunakan untuk mengetahui persepsi kemudahan dan kegunaan SAK EMKM dalam penerapannya di UMKM sektor pertanian. Setelah itu model ini dapat digunakan untuk mengidentifikasi hubungan dan pengaruh penerapan SAK EMKM ini terhadap pengembangan bisnis berbasis digital. Hal ini 
dilakukan karena tantangan yang cukup besar bagi sektor ini adalah adanya industri 4.0. Berikut adalah modifikasi model TAM dari Davis, 1989.

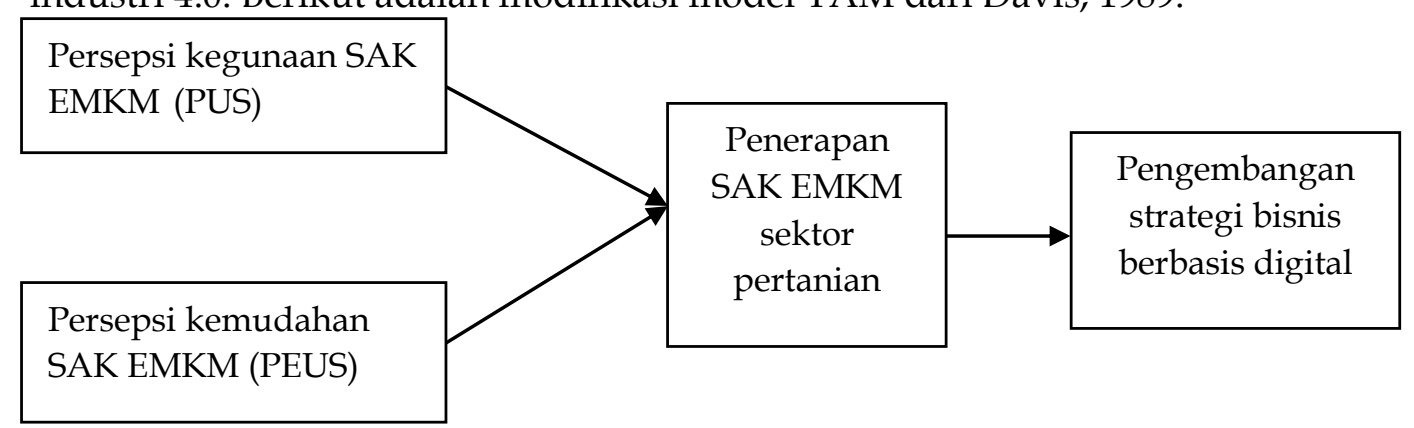

\section{Gambar 1. Modifikasi Technology Acceptance Model}

Sumber: Data Penelitian, 2020

\section{METODE PENELITIAN}

Penelitian ini dilakukan pada usaha kecil, mikro dan menengah sektor pertanian, Kabupaten Bogor. Alasan dipilih lokasi Kabupaten Bogor karena UMKM dan sektor pertanian memiliki kontribusi terhadap PDRB Kabupaten Bogor (Fasiol, 2018) tetapi pertumbuhan usaha sektor ini diprediksi tidak signifikan bahkan beberapa daerah mengalami penurunan (Maulana, 2019).

Data primer diperoleh dari kuesioner yang diberikan ke 100 responden yang tersebar di 40 kecamatan Kabupaten Bogor dengan pemilihan responden dilakukan secara acak. Data yang diperoleh kemudian akan diolah supaya dapat digunakan untuk memetakan persepsi kegunaan dan kemudahan penerapan Standar Akuntansi Keuangan Entitas Mikro Kecil dan Menengah bagi UMKM sektor pertanian. Sedangkan pertanyaan di kuesioner didesain menggunakan model persepsi dari Davis 1989 yang dikenal dengan Technology Acceptance Model.

Model ini pada awalnya digunakan untuk menganalisis penggunaan teknologi informasi, yaitu karyawan mau menggunakan teknologi informasi jika dipandang memiliki kegunaan dibandingkan dengan kemudahan penggunaan. Pada penelitian ini TAM digunakan untuk mengetahui persepsi yang dimiliki oleh pengelola UMKM mengenai kegunaan dan kemudahan penggunaan SAK EMKM dalam menyediakan laporan keuangan sehingga pada akhirnya para pelaku UMKM memutuskan menerapkan SAK EMKM ini dalam pengelolaan keuangannya. Kemudian untuk mengetahui persepsi para pelaku UMKM terkait strategi bisnisnya di era industri 4.0.

Selanjutnya desain penelitian menerapkan studi deskriptif didasarkan pada konsep fenomonologi dari (Putra, 2018). Studi deskriptif merupakan studi yang memberikan penjelasan fakta sesuai adanya sedangkan studi fenomologi memberikan penjelasan mengenai fenomena yang terjadi yang didasarkan dari sumber primer misalnya wawancara dengan responden. Desain penelitian ini diharapkan dapat memberikan gambaran mengenai penerapan SAK EMKM, dan memetakan persepsi kegunaan dan kemudahan penerapan SAK EMKM serta pengembangan bisnis UMKM ini selanjutnya. 


\section{HASIL DAN PEMBAHASAN}

Sebanyak 100 kuesioner disebar ke pelaku UMKM sektor pertanian di Kabupaten Bogor. Responden ini tersebar di beberapa kecamatan diantaranya terdiri dari kecamatan: Dramaga, Parung, Sukaraja, Cigombong, Caringin, Ciawi, Cisarua, Cibinong, Ciapus, Rancabungur, Ciomas, Tenjolaya. Pemilihan responden ini didasarkan pada jenis usaha pertanian yang melibatkan unsur akresi dalam mengembangkan produk usahanya. Akresi ini diartikan sebagai bertambahnya nilai akibat adanya pertumbuhan fisis atau proses alamiah (Suwardjono., 2016). Dari hasil survey lapangan terhadap para responden berikut merupakan sebagian jenis usaha sektor pertanian yang dijalankan oleh responden.

Tabel 1. Data Jenis Usaha UMKM Sektor Pertanian Kabupaten Bogor

\begin{tabular}{clcl}
\hline No & Jenis Usaha & No & Jenis Usaha \\
\hline 1 & Jambu merah & 6 & Ikan hias \\
2 & Jamur & 7 & Ternak Sapi \\
3 & Sayuran & 8 & Ternak ulat \\
4 & Tanaman hias & 9 & Ternak ayam \\
5 & Tanaman pelindung & 10 & Palawija \\
\hline
\end{tabular}

Sumber: Data Penelitian, 2020

Kuesioner yang terdiri dari pertanyaan-pertanyaan terkait profil responden, pengetahuan pengelolaan keuangan UMKM, pengetahuan mengenai SAK EMKM, persepsi kegunaan SAK EMKM, persepsi kemudahan SAK EMKM, penerapan SAK EMKM, dan pengembangan strategi bisnis yang dijalankan oleh UMKM memberikan deskripsi bagaimana sebenarnya SAK EMKM ini diterapkan oleh pelaku UMKM di sektor pertanian. Apakah mereka memiliki persepsi tertentu terhadap kegunaan dan kemudahan penerapan SAK EMKM?

Tabel 2. Pelaku UMKM Berdasarkan Jenis Kelamin

\begin{tabular}{clcc}
\hline No & Jenis Kelamin & Frekuensi & Persentase \\
\hline 1 & Laki-laki & 84 & 84 persen \\
2 & Perempuan & 16 & 16 persen \\
\hline
\end{tabular}

Sumber: Data Penelitian, 2020

Setelah data dari kuesioner dikumpulkan, data kemudian dipilah dan ditabulasi untuk memberikan gambaran lebih lanjut mengenai apa fakta yang ada di masyarakat. Fenomena apa yang sebenarnya ada di para pelaku UMKM sektor ini. Berikut deskripsi dari hasil kuesioner para pelaku UMKM di sektor pertanian Kabupaten Bogor. Dari 100 pelaku UMKM sektor pertanian di Kabupaten Bogor 84 persen diantaranya adalah laki-laki. Sedangkan 16 persen pelaku UMKM adalah perempuan dapat dilihat pada Tabel 2.

Tabel 3. Pelaku UMKM Berdasarkan Usia

\begin{tabular}{clcl}
\hline No & Usia & Frekuensi & Persentase \\
\hline 1 & $15-30$ & 12 & 12 persen \\
2 & $30-40$ & 16 & 16 persen \\
3 & $40-50$ & 33 & 33 persen \\
4 & $50-60$ & 26 & 26 persen \\
5 & $>60$ & 13 & 13 persen \\
\hline
\end{tabular}

Sumber: Data Penelitian, 2020

Jika berdasarkan usia, responden penelitian ini memiliki variasi yang cukup beragam dengan komposisi usia pelaku usaha terbanyak berada di usia 40 
- 50 tahun. Usia pelaku lain juga ada yang 40 tahun ke bawah sekitar 28 persen dari total responden. Usia yang masih cukup produktif.

Dilihat dari latar belakang pendidikan, para pelaku UMKM didominasi oleh lulusan SMA, SD, dan SMP dengan masing-masing memiliki porsi 36 persen, 29 persen, dan 23 persen. Sisanya merupakan lulusan Diploma sebanyak 2 persen, Sarjana 7 persen, dan lainnya 3 persen Tabel 4 .

Tabel 4. Pelaku UMKM Berdasarkan Pendidikan

\begin{tabular}{clcc}
\hline No & Pendidikan & Frekuensi & Persentase \\
\hline 1 & Tidak tamat SD & - & - \\
2 & SD & 29 & 29 persen \\
3 & SMP & 23 & 23 persen \\
4 & SMA & 36 & 36 persen \\
5 & Diploma & 2 & 2 persen \\
6 & Sarjana & 7 & 7 persen \\
7 & Pascasarjana & - & - \\
8 & Lainnya & 3 & 3 persen \\
\hline
\end{tabular}

Sumber: Data Penelitian, 2020

Rata-rata UMKM dijalankan oleh responden lebih dari 10 tahun yaitu sebanyak 42 pelaku UMKM. 29 persen pelaku UMKM menggeluti usahanya antara 3 - 5 tahun. Sisanya 15 persen selama 5 - 10 tahun dan 14 persen usaha kurang dari 3 tahun. Hasil olah data dapat dilihat di Tabel 5.

Tabel 5. Kategori UMKM Berdasarkan Lama Usaha

\begin{tabular}{clcl}
\hline No & Lama Usaha & Frekuensi & Persentase \\
\hline 1 & $<3$ tahun & 14 & 14 persen \\
2 & $3-5$ tahun & 29 & 29 persen \\
3 & $5-10$ tahun & 15 & 15 persen \\
4 & $>10$ tahun & 42 & 42 persen
\end{tabular}

Sumber: Data Penelitian, 2020

Sesuai Tabel 6, responden memiliki omzet rata-rata di 41 - 60 juta sebanyak 37 persen dan sampai 20 juta sekitar 32 persen. Dari komposisi ini hanya sekita 10 persen yang memiliki omzet melebihi 100 juta. Sisanya 18 persen memperoleh omzet 21 - 40 juta. Dan hanya 3 persen memperoleh omzet antara 61 - 80 juta per bulan.

Tabel 6. Kategori UMKM Berdasarkan Omzet Usaha

\begin{tabular}{clcc}
\hline No & Omzet & Frekuensi & Persentase \\
\hline 1 & $0-20$ juta & 32 & 32 persen \\
2 & $21-40$ juta & 18 & 18 persen \\
3 & $41-60$ juta & 37 & 37 persen \\
4 & $61-80$ juta & 3 & 3 persen \\
5 & $81-90$ juta & - & - \\
6 & $>100$ juta & 10 & 10 persen \\
\hline
\end{tabular}

Sumber: Data Penelitian, 2020

Hasil olah data dari jawaban pertanyaan yang ada di kuesioner kemudian menggunakan skala likert yang menunjukkan kategori Sangat Setuju (SS), Setuju (S), Ragu-ragu (R), Tidak Setuju (TS), dan Sangat Tidak Setuju (STS) menunjukkan komposisi data seperti yang ada di Tabel 7. Dari respons responden terhadap pertanyaan mengenai pengetahuan laporan keuangan, lebih 
dari 60 persen responden menjawab bahwa laporan keuangan sangat penting dan bermanfaat bagi UMKM. Kemudian para pelaku ini umumnya mengakui bahwa mereka memang menghadapi kendala modal dari lembaga keuangan (sebanyak 40 persen) sisanya mereka menganggap masalah yang paling sering mereka hadapi di usaha mereka adalah pemasaran produk.

Selain itu, ketika dikonfirmasi apakah UMKM mendapatkan kendala modal dari lembaga keuangan karena laporan keuangan yang tidak terpercaya, sebanyak 39 persen membenarkan hal ini tetapi 34 persen justru tidak setuju. Sama halnya dengan pertanyaan apakah kendala modal ini karena laporan keuangan yang tidak sesuai dengan standar, responnya hampir seimbang antara yang setuju dan tidak setuju yaitu 35 persen dan 36 persen. 27 persen malah ragu-ragu. Hal ini menunjukkan sebenarnya kendala mendapatkan modal tidak hanya dari laporan keuangan yang tidak terpercya tetapi juga dari laporan keuangan yang tidak sesuai standar.

Tabel 7. Pengetahuan Pengelolaan Keuangan

\begin{tabular}{cccccc}
\hline Pertanyaan & SS & S & R & TS & STS \\
\hline P1 & 4 & 56 & 19 & 21 & - \\
P2 & 19 & 64 & 5 & 12 & - \\
P3 & 19 & 68 & 1 & 12 & - \\
P4 & 5 & 40 & 27 & 28 & - \\
P5 & 4 & 39 & 23 & 34 & - \\
P6 & 2 & 35 & 27 & 36 & -
\end{tabular}

Sumber: Data Penelitian, 2020

Berdasarkan Tabel 8, hasil olah data menunjukkan tingkat pengetahuan pelaku UMKM terhadap SAK EMKM. Dari pertanyaan terkait pengetahun SAK EMKM, para responden setuju bahwa Standar Akuntansi Keuangan merupakan panduan untuk pembuatan laporan keuangan, terbukti lebih dari 40 persen memberikan respons setuju. Tetapi ketika dikonfirmasi apakah mereka pernah mendengar informasi mengenai SAK EMKM, umumnya para pelaku UMKM ini malah tidak mengetahui informasi mengenai SAK EMKM baik itu dari atasan di tempat usaha, internet, pesaing usaha, asosiasi usaha, ataupun pemerintah, lebih dari 70 persen responden memberikan respon tidak setuju.

Tabel 8. Pengetahuan SAK EMKM

\begin{tabular}{cccccc}
\hline Pertanyaan & SS & S & R & TS & STS \\
\hline P1 & 6 & 59 & 23 & 16 & - \\
P2 & 3 & 45 & 27 & 25 & - \\
P3 & 5 & 47 & 30 & 18 & - \\
P4 & - & 9 & 5 & 83 & 3 \\
P5 & - & 14 & 10 & 73 & 3 \\
P6 & - & 9 & 12 & 76 & 3 \\
P7 & 1 & 15 & 7 & 74 & 3 \\
P8 & 2 & 11 & 8 & 70 & 9 \\
\hline
\end{tabular}

Sumber: Data Penelitian, 2020

Pertanyaan-pertanyaan yang terkait dengan kegunaan SAK EMKM didesain untuk mengetahui persepsi pelaku UMKM sebagai pengguna. Berdasarkan hasil dari kuesioner terhadap 100 responden, dominannya mereka memiliki persepsi bahwa SAK EMKM dapat menyediakan informasi untuk 
pengambilan keputusan, menyediakan dokumen yang dibutuhkan untuk bank, mempermudah pengendalian dan pengelolaan keuangan dan dapat mempermudah membuat laporan, dengan respons setuju rata-rata lebih dari 30 persen. Tetapi sebagian besar dari responden juga ragu terhadap persepsi ini, ditunjukkan dengan respons antara 20 persen - 30 persen. Gambaran lebih lengkap komposisi ini dapat dilihat di Tabel 9.

Tabel 9. Persepsi Kegunaan

\begin{tabular}{cccccc}
\hline Pertanyaan & SS & S & R & TS & STS \\
\hline P1 & 2 & 38 & 36 & 24 & - \\
P2 & 7 & 37 & 30 & 26 & - \\
P3 & 5 & 39 & 27 & 29 & - \\
P4 & 2 & 35 & 26 & 35 & - \\
\hline
\end{tabular}

Sumber: Data Penelitian, 2020

Lain halnya dengan persepsi kegunaan dari para pelaku UMKM, Tabel 10, menunjukkan hasil olah data untuk mengetahui persepsi kemudahan SAK EMKM untuk diterapkan di usaha mereka. Dominannya responden memiliki persepsi tidak setuju bahwa SAK EMKM memberikan kemudahan untuk dipelajari dan diterapkan (40 persen dan 30 persen), sebanyak 39 persen dan 45 persen menunjukkan keraguan akan dua unsur ini. Tetapi para responden juga tidak begitu paham apakah SAK EMKM ini akan memberikan biaya tambahan atau tidak misalnya tambahan karyawan untuk pengerjaannya atau tambahan alat untuk membantu kemudahan penerapannya. Hal ini ditunjukkan dengan respons ragu yang masing-masing lebih dari 40 persen.

Tabel 10. Persepsi Kemudahan

\begin{tabular}{cccccc}
\hline Pertanyaan & SS & S & R & TS & STS \\
\hline P1 & 1 & 19 & 39 & 40 & 1 \\
P2 & 2 & 19 & 45 & 33 & 1 \\
P3 & - & 29 & 43 & 27 & 1 \\
P4 & 1 & 22 & 44 & 33 & - \\
P5 & 1 & 31 & 40 & 27 & 1 \\
\hline
\end{tabular}

Sumber: Data Penelitian, 2020

Di sisi lain para responden juga ragu apakah SAK EMKM ini memudahkan pertukaran informasi atau tidak (44 persen), dari 33 persen responden malah tidak setuju bahwa SAK EMKM ini memberikan kemudahan yang dimaksud. Hanya sekitar 22 persen yang setuju bahwa SAK EMKM akan memberikan kemudahan pertukaran informasi antar unit atau divisi dalam usaha (23 persen).

\section{Tabel 11. Penerapan SAK EMKM}

\begin{tabular}{cccccc}
\hline Pertanyaan & SS & S & R & TS & STS \\
\hline P1 & 8 & 35 & 15 & 39 & 3 \\
P2 & 6 & 33 & 21 & 35 & 5 \\
P3 & 5 & 25 & 23 & 44 & 3 \\
P4 & 2 & 19 & 18 & 55 & 6 \\
\hline
\end{tabular}

Sumber: Data Penelitian, 2020

Di Tabel 11, hasil olah data dari penelitian ini menggambarkan bagaimana respons responden ketika dikonfirmasi mengenai kebersediaan mereka untuk menerapkan SAK EMKM dalam usahanya. Dari dua pertanyaan 
yang terkait dengan apakah pelaku UMKM akan mempelajari dan menggunakan SAK EMKM dalam usahanya, respons yang diterima adalah dominannya setuju dengan proporsi 43 persen dan 39 persen tetapi proporsi besar lainnya malah tidak setuju dengan respons 42 persen dan 40 persen. Sisanya menunjukkan respons ragu-ragu. Dari 100 responden ini memberikan respons tidak setuju dan ragu ketika dikonfirmasi mengenai kesediaan untuk mensosialisasikan penerapan SAK EMKM, lebih dari 60 persen responden bahkan menyatakan tidak menggunakan SAK EMKM di dalam usahanya.

Terkait dengan pengembangan bisnis, para pelaku UMKM sektor pertanian Kabupaten Bogor ini telah mengenal teknologi. Tetapi para responden tidak paham bagaimana teknologi ini dapat membantu secara optimal usaha mereka misalnya dengan menggunakan alat social media (sosmed) dan penjualan online. Sebanyak lebih dari 50 persen mengetahui adanya sosmed tetapi tidak menggunakan sosmed untuk usahanya. Sebanyak lebih dari 56 persen dari responden juga paham bahwa gawai dapat digunakan untuk promosi hasil pertanian atau produk responden. Namun demikian lebih dari 54 persen responden tidak setuju untuk menjual hasil produknya secara online.

Tabel 12. Pengembangan Strategi Bisnis

\begin{tabular}{cccccc}
\hline Pertanyaan & SS & S & R & TS & STS \\
\hline P1 & 3 & 36 & 10 & 50 & 1 \\
P2 & 6 & 56 & 8 & 29 & 1 \\
P3 & 5 & 27 & 13 & 54 & 1
\end{tabular}

Sumber: Data Penelitian, 2020

\section{SIMPULAN}

Merujuk pada hasil olah data kuesioner yang telah disebarkan ke 100 responden yang merupakan 100 pelaku UMKM di sektor pertanian Kabupaten Bogor, dapat disimpulkan bahwa para pelaku sebenarnya mengetahui ada kendala dalam pemerolehan modal dari lembaga keuangan terkait dengan kurang dapat dipercayanya laporan keuangan. Tetapi perhatian para responden lebih pada mempertimbangkan pemasaran produk mereka ke konsumen.

Terkait dengan pengetahun pengelolaan keuangan para responden sektor ini mengakui bahwa laporan keuangan itu penting dan bermanfaat. Tetapi hampir semua responden UMKM sektor pertanian merasa bahwa mereka tidak pernah memperoleh informasi ini. Walaupun jika dikonfirmasi mengenai persepsi kegunaan SAK EMKM, para responden dominannya setuju. Namun demikian berbeda dengan persepsi para responden tentang kegunaan, persepsi mereka terhdap kemudahan penerapan SAK EMKM sebagai panduan pembuatan laporan keuangan, responsnya lebih ke arah tidak setuju. Dan hampir semua responden memang tidak menerapkan SAK EMKM di usaha bisnisnya.

Terkait dengan penggunaan teknologi untuk pengembangan bisnis, tidak diketahui apakah ada pengaruh persepsi kegunaan dan kemudahan penerapan SAK EMKM dalam usaha bisnis para responden, tetapi para pelaku UMKM ini baru mengetahui teknologi hanya sebatas dapat membantu kegiatan promosi usahanya. Para pelaku UMKM ini belum paham bahwa dunia digital juga dapat digunakan untuk transaksi penjualan. Keterbatasan penelitian ini adalah lingkup 
para pelaku UMKM sektor pertanian di Kabupaten Bogor, mungkin jika dibandingkan dengan daerah lain atau UMKM sektor lain akan menghasilkan interpretasi yang berbeda begitu juga dengan metode analisis lain misalnya analisis kuantitatif yang melihat hubungan antara PUS dan PEUS terhadap Intention to Use pelaku UMKM sektor pertanian. Sehingga saran untuk penelitian selanjutnya dapat menggunakan metode analisis kuantitatif dengan alat uji statistik atau Structural Equation Model (SEM).

Terakhir, penelitian ini terlaksana dengan dana hibah dari RISTEK-BRIN. Sehingga dengan terselesaikannya artkel ini, tim peneliti mengucapkan terima kasih kepada RISTEK_BRIN dan Lembaga Penelitian dan Pengabdian Masyarakat (LPPM) Universitas Pakuan. Penelitian ini juga dilaksanakan dengan mempertimbangkan protokol kesehatan.

\section{REFERENSI}

Abdelhafid, M., \& Mohammed, S. (2019). The Impact of Information Asymmetry on the Bank Financing of SMEs in Algeria: An Econometric Study. International Journal of Inspiration \& Resilience Economy, 3(1), 17-23. doi: http://article.sapub.org/10.5923.j.ijire.20190301.03.html

Agung, A., Latuheru, P., B., , \& Persuless, G. (2018). Faktor-Faktor Yang Mempengaruhi Penerapan Standar Akuntansi Keuangan Entitas Tanpa Akuntabilitas Publik (Studi Empiris pada UMKM di Kota Ambon). PELUANG. Jurnal Ekonomi Peluang. doi: http://ojs.ukim.ac.id/index.php/peluang/article/view/327

Amoako-Gyampah, K., \& Salam, A. F. (2004). An extension of the technology acceptance model in an ERP implementation environment. Information and Management, 41(6), 731-745. doi: https://doi.org/10.1016/j.im.2003.08.010

Undang-Undang Nomor 20 Tahun 2008 Tentang Usaha Mikro, Kecil, dan Menengah. https://www.ojk.go.id/sustainablefinance/id/peraturan/undang-undang/Pages/Undang-UndangRepublik-Indonesia-Nomor-20-Tahun-2008-Tentang-Usaha-Mikro,-Kecil,dan-Menengah.aspx (2008).

Davis, F. D. (1989). Perceived usefulness, perceived ease of use, and user acceptance of information technology. MIS Quarterly: Management Information Systems, 13(3), 319-339. doi: https://doi.org/10.2307/249008

Deaconu, A., \& Buiga, A. (2015). Financial reporting and mimetic theory for small and medium enterprises. Current Science, 108(3), 334-340. doi: https://www.researchgate.net/publication/279332590_Financial_reporti ng_and_mimetic_theory_for_small_and_medium_enterprises

Erasmus, E., Rothmann, S., \& Van Eeden, C. (2015). A structural model of technology acceptance. SA Journal of Industrial Psychology, 41(1). doi: https://doi.org/10.4102/sajip.v41i1.1222

Fasiol, A. (2018). PDRB Kabupaten Bogor Lampau PDB Nasional dan Jawa Barat. Beritautama.Net. Retrieved from https://beritautama.net/news/pdrbkabupaten-bogor-lampaui-pdb-nasional-dan-jawa-barat/

Huang, C., When, Y., \& Liu, Z. (2014). Analysis on Financing Difficulties for SMEs due to Asymmetric Information. Global Disclosure of Economics and Business,, 3(1), 77-80. doi: https://doi.org/10.18034/gdeb.v3i1.174 
Kaya, D., \& Koch, M. (2015). Countries adoption of the International Financial Reporting Standard for Small and Medium-sized Entities (IFRS for SMEs) - Early empirical evidence. Accounting and Business Research, 45(1), 93-120. doi: https:/ / doi.org/10.1080/00014788.2014.969188

Kersten, R., Harms, J., Liket, K., \& Maas, K. (2017). Small Firms, large Impact? A systematic review of the SME Finance Literature. In World Development 97, 330-348. doi: https://doi.org/10.1016/j.worlddev.2017.04.012

Kiliç, M., Uyar, A., \& Ataman, B. (2016). Preparedness of the entities for the IFRS for SMEs: an emerging country case. Journal of Accounting in Emerging Economies, 6(2), 156-178. doi: https://doi.org/10.1108/jaee-01-2014-0003

Maulana, A. G. (2019). Unpak Bogor Minat Uji Warga Terhadap Pertanian. https://www.ayobogor.com/read/2019/05/31/3524/unpak-bogor-minat-uji-wargaterhadap-pertanian.

Nerissa, P., P., , \& Hapsari, W., D. . (2018). Pengaruh Persepsi Kegunaan dan Persepsi Kemudahan Terhadap Implementasi SAK-ETAP (Studi Kasus Pada UMKM Kota Bandung Tahun 2017). Paper presented at the E-Proceeding of Management. https://123dok.com/document/qmvjxg7q-pengaruhpersepsi-kegunaan-persepsi-kemudahan-implementasi-studibandung.html

Önday, Ö. (2018). What Would Be the Impact of Industry 4.0 on SMEs: The Case of Germany. The International Journal of Management, 7(2), 11-19. doi: https://www.researchgate.net/publication/324888680_What_Would_Be _the_Impact_of_Industry_40_on_SMEs_The_Case_of_Germany

Perera, D., \& Chand, P. (2015). Issues in the adoption of international financial reporting standards (IFRS) for small and medium-sized enterprises (SMES). Advances in Accounting, 31(1), 1-14. doi: 10.1016/j.adiac.2015.03.012

Permatasari, C. L., Yanto, H., \& Widiyanto, W. (2017). Penerimaan Pernyataan Standar Akuntansi Keuangan Oleh Pengelola Keuangan Yayasan Pendidikan: Analisis Technology Acceptance Model. Journal of Economic Education, 5(1), 90-99. doi: https://journal.unnes.ac.id/sju/index.php/jeec/article/view/13022

Purbaya, A. A. (2019). Masalah UMKM di RI: Minim Melek Teknologi hingga Sulit Akses Modal. . https://finance.detik.com/berita-ekonomi-bisnis/d4464791/masalah-umkm-di-ri-minim-melek-teknologi-hingga-sulit-akses-modal.

Putra, A. D. (2018). UMKM Sumbang 60 Persen ke Pertumbuhan Ekonomi Nasional. Bisnis Liputan6.com, https://www.liputan6.com/bisnis/read/3581067/umkm-sumbang-60-persen-kepertumbuhan-ekonomi-nasional.

Putra, Y. M. (2018). Pemetaan Penerapan Standar Akuntansi Keuangan Emkm pada UMKM di Kota Tangerang Selatan Profita: Komunikasi Ilmiah Dan Perpajakan, 11(2), 201-217. doi: 10.22441/profita.2018.v11.02.004

Rizal, A. (2014). Analisis Penerapan Project Management Information System (PMIS) Menggunakan Metode Technology Acceptance Model (TAM) Studi Kasus PT. INDOSAT, Tbk. Jurnal Telekomunikasi Dan Komputer, 5(1), 1-24. doi: https://doi.org/10.22441/incomtech.v5i1.1131 
Rusmanah, E., Andria, F., \& Irawan, A. W. (2019). Implementasi Digital Marketing Guna Peningkatan Peluang Pasar Produksi Hasil Ternak Puyuh Masyarakat Desa Galuga Jurnal ABM Mengabdi, 6(1), 14-25. doi: http://jabm.stie-mce.ac.id/index.php/jam/article/view/422

Saito, K., \& Tsuruta, D. (2018). Information asymmetry in small and medium enterprise credit guarantee schemes: evidence from Japan. Applied Economics, 50(22), 2469-2485. doi: https://doi.org/10.1080/00036846.2017.1400651

Schröder, C. (2016). The Challenges of Industry 4.0 for Small and Medium-sized Enterprises.

https://www.researchgate.net/publication/305789672_The_Challenges_ of_Industry_40_for_Small_and_Medium-sized_Enterprises.

Suwardjono. (2016). Teori Akuntansi, Perekayasaan Pelaporan Keuangan: BPFEYogyakarta.

Tang, S., \& Guo, S. (2017). Formal and Informal Credit Markets and Rural Credit Demand in China. Paper presented at the 4th International Conference on Industrial Economics System and Industrial Security Engineering (IEIS), http:/ / toc.proceedings.com/36406webtoc.pdf

Yasar, A., \& Gokhan, O. (2012). The Use of Technology Acceptance Model in Enterprise Resource Planning Implementations. Business and Economics Research Journal, 3(2), 79-96. doi: https://www.berjournal.com/the-useof-technology-acceptance-model-in-enterprise-resource-planningimplementations

Yasmin, P. A. (2018). Jadi Penggerak Ekonomi, Begini Kondisi UMKM RI. https://finance.detik.com/berita-ekonomi-bisnis/d-4119386/jadi-penggerakekonomi-begini-kondisi-umkm-ri. 